\title{
実践研究
}

\section{ごっこ遊び場面における重度精神遅滞児の コミュニケーション行動の指導} 一同じテーマの遊びへの般化の検討一

\author{
宮 崎 真*・岡 田 佳世美*・水 村 和 子**
}

\begin{abstract}
本研究の目的は、重度精神遅滞女児 (CA9：0, MA1：8, IQ19)に、ごっこ遊びルーティン を指導する中で形成した発話行動が同じテーマの遊びに般化するか検討することであった。 集団は精神遅滞児 4 名（自閉児 1 名を含む）から構成された。ごっこ遊びのストーリーは役 決め、買い物、食事の 3 場面から成った。各対象児は、お店屋さん役か子ども役いずれかを 分担し、ストーリーに沿ってコミュニケーション行動やその他の行動から成る行動の系列を 遂行するように指導された。対象児が行動すべき時に無反応であった場合、プロンプターは 示唆、指示、示範いずれかの援助を行った。指導の結果、全行動の平均遂行率は向上し、数 語を獲得した。また、指導したコミュニケーション行動とその他の行動は、他の買い物ごっ こルーティンに般化した。
\end{abstract}

キー・ワード：重度精神遅滞児 ごっこ遊び ルーティン コミュニケーション 般化

\section{I. 問 題}

ごっこ遊びに熱中する中で、子どもは、認知、社会 性あるいは言語等の様々な能力を発達させる、という 考え方に沿って、筆者はごっこ遊びを言葉指導に適用 する可能性を検討してきた（宮崎, $1992^{22}$; 宮崎, $\left.1995^{3)}\right)$ 。その際、言葉指導にごっこ遊びを関連づける 仮説は次の通りである。お店屋さんとお客さんのよう に役割を分担させることによって、参加者を社会的に 関連づけ、ストーリーに沿って相互交涉を行わせる機 会を設けることができる（Strain and Wiegerink, $\left.1976^{5)}\right)$ 。この相互交涉の機会を捉えて、対人行動やコ ミュニケーション行動を指導することができるだろ う。しかし、重度の精神遅滞を持つ子ども（以下遅滞 児と略す) や自閉児は、ごっこ遊びを自ら行うことが できない。そこで、ごっこ遊びを一定のテーマによっ て統一された、対人行動と非対人行動から成るルー ティンとして指導者が構成化し、系統的な指導を実施 すれば、コミュニケーション行動を形成・促進できる であろう。

\section{*東京学芸大学附属養護学校}

**東京学芸大学
このような立場から、宮崎 $\left(1992^{2)}\right)$ は、責護学校小 学部児童 5 名に、カレーライスごっこを導入した。そ して、普段は自分の伝達意図を周囲の大人から読み とってもらっていた児童が「指さし」や「頂戴ジェス チャー」による伝達ができるようになった。また「頂 戴ジェスチャー」が家庭や他の学校場面でも使われた ことを報告している。宮崎 $\left(1995^{3)}\right)$ は、宝探しごっこ で、小学校心障学級在籍の自閉児および重度遅滞児に 発話行動を指導した。その結果、「クダサイ」「アリガ トウ」を形成することができた。般化場面で両対象児 ともに般化が認められたことを報告している。

以上の指導では、課題が幾つか残されている。その 1 つは、般化の問題である。宮崎 $\left(1992^{2)}\right)$ の報告は、 般化の現象が逸話的な記述にとどまっている。また、 宮崎 $\left(1995^{3}\right)$ の報告では、指導で利用した場面に 1 場 面を加えた場面で般化を評価しているだけである。

般化は、ごっこ遊びの指導を評価する上で重要な指 標であると考えられる。般化の有無によって、形成し たごっこ遊びが、ある行動系列のパターン化に止まっ たか、象徵的な遊びにまで達したかを判断することが できるからである。ごっこ遊びは、参加者がテーマを 共有し、テーマに従って、目の前の環境に象徵的な意 
味を与えることによって成立する。ごっこ遊びの中で 重度遅滞児が象微的行動を遂行したとしたら、多少遊 具や場所が違った環境の下でも、同じテーマのごっこ 遊びを行えるだろう。しかし、非言語性精神年龈が 20 力月以下の重度遅滞児は見立て遊びを自発的に遂行で きなかったり、ステレオタイプな遊びを繰り返すこと から (Wing, Gould, Yeates, and Brierley, 19777) 、 一定のごっこ遊びを形成することができても、遊びは 指導で使われた遊具や場所に依存したり、限定され、 般化し難いことが予想される。そこで、般化を評価し たり、般化を促す手続きを用意することが、融通のき くごっこ遊びに近づけることに貢献するものと考えら れる。

般化を促す要因として、指導計画の中に複数の場面 を導入することが指摘されている（Stokes and Baer, $\left.1977^{4)}\right)$ 。そこで、本研究ではこの点に着目し、ルーティ ンをほぼ等しく保ち、お店の種類や品物、また品物の 展示の仕方を変えた 3 場面を順次導入した。本研究の 目的は、ごっこ遊びを構成するコミュニケーション行 動を含めた役割行動の形成と同じテーマの遊びへの般 化を促すことである。

\section{II. 方 法}

\section{1 . 対象児}

精神遅滞女児（以下，M 児と略す)。1993 年 6 月現 在、9才 0 力月、MA 1 才 8 力月、IQ 19 (改訂田研式田 中ビネー検查)。2才台で通過した項目は動作性の項目 である（碁石の分類，縦続引き，紐通し）。一方、言語 性の項目は 1 才台の身体各部位の指示のみが通過し た。SA 3 才 10 力月、SQ 42(SM 社会性発達検查)。領 域別の SA は、身辺自立が 4 才 8 力月、移動が 5 才 7 力 月、作業や 3 才 3 力、意志交換が 1 才 3 力月、集団 参加が 3 才 7 力月。両検査の結果から、言葉の理解や 表出が特に遅滞していることが分かる。本児は、声が 小さく、また構音が不明瞭で、発声は「シャシャシャ」 と聞こえる場合が多い。指導開始当初、母親の主訴は、 「自発的な行動が取れるようにしたい。物の名前を理 解し、言葉が多く出るように」ということであった。 本児が好むごっこ遊びを使うことによって、積極的な 行動を増加させると共に、コミュニケーション行動の 指導を行うこととした。また、指導の対象とする語の 選定に際して、比較的発声のし易い語を選択すること とした。

\section{2 . 指導期間 - 場所}

1993 年 6 月〜 12 月、毎週 1 回、計 17 セッション、
プレールーム $(7 \times 7 \mathrm{~m})$ において指導を実施した。指 導時間は 1 セッション当たり約 30 分で形式は集団指 導である。

\section{3. 指導計画}

ABA 除去計画に扔むね沿った指導計画を立て た。指導の流れとして、買い物ごっこスクリプト（以 下，台本とする） A・ベースライン期（A・BL 期）、台 本 $\mathrm{A}$ 指導期（A・Tr 期）、台本 $\mathrm{A}$ ・ベースライン期（維

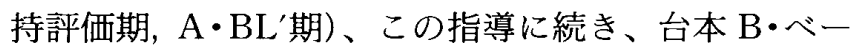
スライン期（台本 $\mathrm{A}$ の般化評価期を兼ねる. B・BL 期）、台本 $B$ 指導期（B・Tr 期）、台本・ベースライン 期 (維持評価期, $\mathrm{B} \cdot \mathrm{BL}$ 期)、台本 $\mathrm{C}$ 期（台本 $\mathrm{B}$ の般 化評価期，C・BL 期）を設定した。台本 $\mathrm{A} 、 \mathrm{~B} 、 \mathrm{C}$ は、 いずれも買い物ごっこであるが、お店の構造や外観、 それに品物を変えたりしており、台本に若干の違いが ある。

\section{4 . 集団構成}

集団は、 $M$ 児を含む遅滞児 3 名と自閉症児 1 名の計 4 名で構成された。CA の範囲は 8：03-10：11、MA の 範囲は 1：08-2：07、IQ の範囲は 19-30(改訂田研田中 ビネー検查, 1993 年 6 月実施)、SA の範囲は 3 : 10-4：07、SQの範囲は 31-54 であった（S-M 社会生 活能力検查, 同時期実施)。指導にあたる大人は母親役 1 名（遊びの進行役も兼ねる）およびプロンプター4名 (以下, Pr と略す) の計 5 名である。

\section{5 ，指導手続き}

対象児 4 名は、毎セッション子ども役およびお店屋 さん役を交代で受け持った。ごっこ遊びの粗筋は役決 め、買い物、食事であった(Table 1)。この粗筋に沿っ た役割行動を、プロンプト (時間遅延, 示唆, 指示, 示 範）によって形成した。時間遅延とは、対象児が各行 動を遂行すべき場面に到着してから、遂行するまで Pr がおおよそ 10 秒間待つことである。示唆とは、時間遅 延しても、対象児が遂行すべき行動を遂行しない時、

「どうするんだっけ? 小「何って言うの」と教示し、 行動の遂行を促すことである。示唆しても行動を遂行 しない場合、指示（直接行動を言語化し，遂行を促す. 「〜して」と教示する）あるいは示範（Pr が言葉ある いは動作を示し, 模倣させる.「〜って言って」あるい は「やってごらん」と教示する）を提供した。

\section{6. 結果の整理方法}

各セッションをビデオ録画し、その録画を再生し、 次の 3 点から文字転写し、集計した。

1) 台本を構成する各行動単位の遂行：プロンプ トの有無およびその種類(なし, 時間遅延, 示唆, 指示, 


\section{ごっこ遊び場面における重度精神遅滞児のコミュニケーション行動の指導}

Table 1 買い物ごっこ台本Aおよび標的行動

役 割：子ども (抢客) 役 2 名, 抢店役 2 名, 打母さん役 1 名 (大人)

小道具：買い物かご(2), 財布(2), 㧍金, 店のドア(2), レジスター(2), エプロン(2), 牛乳パック, 卵(フェルト製), テー ブル(3)，椅子(5)，皿(3)，コップ(2)，目玉焼き(フェルト製，2）

場面配置：家とそこから約 3 m離れた場所に牛乳を売る店と卵を売る店が並んで位置している

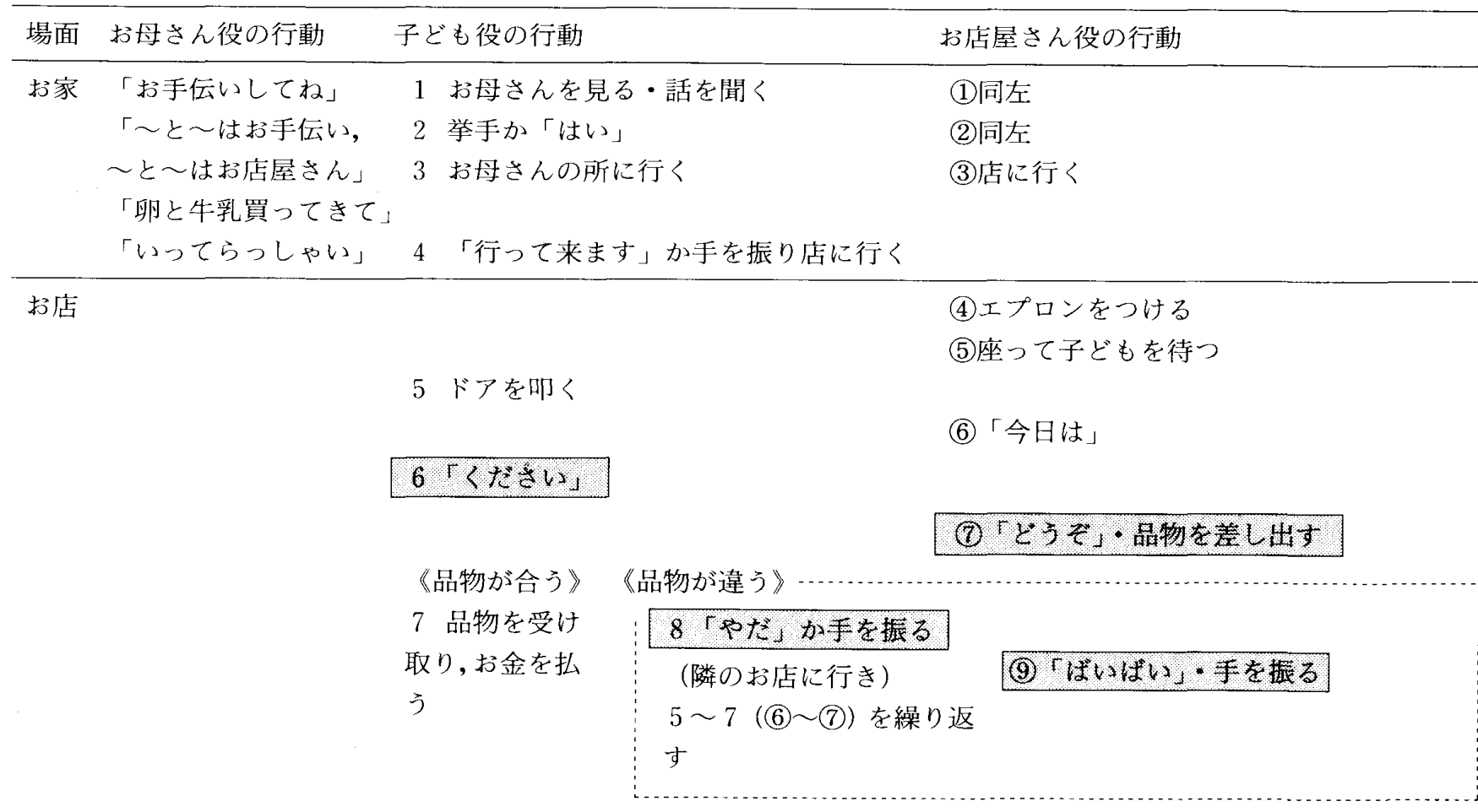

(8)抢金を受け取る

\section{9 「ばいばい,・手を振る}

(9) ゲいばい」・手を振る

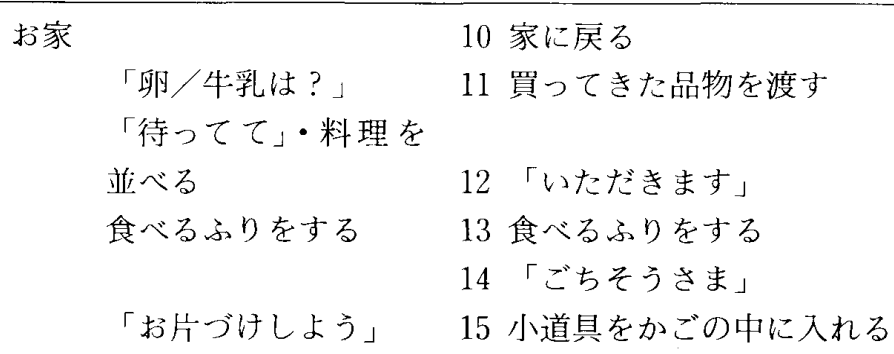

子ども拉よび扔店屋さん役の行動が標的行動,

一が標的コミュニケーション行動

示範）、また各行動単位の遂行水準によって全ての行動 単位を評価した。

「プロンプト無し」とは、指示、示範を受けずに、 遂行した場合である。時間遅延や示晙を受けて遂行し た場合は、「プロンプト無し」に含めた。「プロンプト 有り」とは、指示、示範を受けて遂行した場合である。 また、行動の遂行水準とは、遂行、部分遂行、無・誤 遂行という 3 水準である。行動がその定義に従って遂 行された場合を「遂行」、行動の一部が各行動の咨義に 該当する場合を「部分遂行」、その定義に該当しない場
合や行動が遂行されない場合を「無・誤遂行」とした。 平均遂行率は、各試行毎に、行動の遂行数十部分遂 行数／要請される全行動単位 $\times 100$ の計算式で求め た。

2) 標的としたコミュニケーション行動（子ども 役：行動 $6,8,9$ ，お店屋さん役：行動(7)，(9)：1）の 文字転写記録に加え、標的としたコミュニケーション 行動に関して、各試行毎にPrの発話とM 览の発話お よび身ぶり・動作を文字転写した。

3）台本に含まれないコミュニケーション行動： 
自発的なコミュニケーション行動が生起しやすいと思 われる買い物場面（行動(6)～(9)の間）に生起したコ ミュニケーション行動を文字転写し、McLean and Snyder-McLean (1987 $\left.{ }^{1)}\right)$ の意図的コミュニケーショ ンシグナルの分類（1)接触ジェスチュアー；脇へ押し 出す. 物に働きかける, 大人に働きかける, 提示, 提 供, 物に触れる, 非意図的発声, (2)遠ジェスチュ ア一; 要求, はい・いいえのうなずき, 指さし, 抑揚の ある声, (3)真のサイン・言語（true-sign/linguistic）; 原単語 (proto-words), 単一語 (single-words)) に 従って各コミュニケーション行動を区分した。

\section{7. 信頼性}

台本を構成する全ての行動単位および台本に含まれ ないコミュニケーション行動に関して観察者 2 名によ り一致率を求めた。子ども役およびお店屋さん役各 3 試行での平均一致率はそれぞれ平均 $95.1 \%$ 、平均 91.7\%であった。また、台本に含まれないコミュニケー ション行動は 2 試行について算出した。その平均一致 率は $90 \%$ であった。標的としたコミュニケーション行 動の発話記録は 2 名の観察者の合議に基づき、記述し た。

なお、一致率は、一致数 /一致数十不一致数 $\times 100$ の 計算式で求めた。

\section{III. 結 果}

1、全行動の指導経過 (Fig. 1)

子ども、お店屋さんいずれの役でも、A・Tr期で、
平均遂行率は上昇し、 $\mathrm{A} \cdot \mathrm{BL}^{\prime}$ 期に移っても、指導期最 後の平均遂行率の水準を維持し、 $\mathrm{B} \cdot \mathrm{BL}$ 期でも、同水 準の平均遂行率をほほ維持している。B・Tr指導期で、 指導期前半の平均遂行率が後半より高い。しかし、B・ $\mathrm{BL}^{\prime}$ 期の平均遂行率は、 $\mathrm{B} \cdot \mathrm{BL}$ 期の平均遂行率とほほ 等しく、C・BL 期の平均遂行率は、B・BL'期より高い。 全試行に渡るコミュニケーション行動の遂行率は、 ルーティンを構成する全行動単位の平均遂行率（子ど も役 $75 \%$ ，お店屋さん役 $79 \%$ ）上り低い。

\section{2. 指導の標的としたコミュニケーション行動の指} 導経過（Fig. 2-1, 2-2)

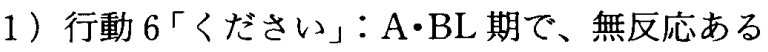
いは不明瞭な発声であった。A・Tr 指導期前半で、示 範に従って「ください」に似た発声に近づき、A・Tr 指導期後半で、自発するようになった。また、この発 話行動は $\mathrm{A} \cdot \mathrm{BL}$ 期および $\mathrm{B} \cdot \mathrm{BL}$ 期で自発された。 $\mathrm{B} ・$ $\operatorname{Tr}$ 期から C・BL 期で、「シェーシェ」に置換される傾 向が認められる。

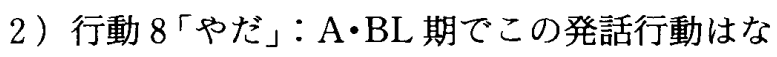
く、A・Tr指導期で「イダ夕」を示範に応じて発した。 $\mathrm{B} ・ \mathrm{BL}$ 期で「ヤダ」を自発した。B・Tr期以後、「押 し返す」「隣を指さす」等の身ぶりにモダリティーを代 え、遂行した。

3) 行動 9 および(9)「ばいばい」: 子ども役の時、 $\mathrm{A} ・ \mathrm{BL}$ 期では身ぶり、発話いずれかで応答し、A・Tr 期中期以降身ぶりあるいは「ダイダイ」など近似した 発声を自発した。お店屋さん役の時、 $\mathrm{A} \cdot \mathrm{Tr}$ 期前期以

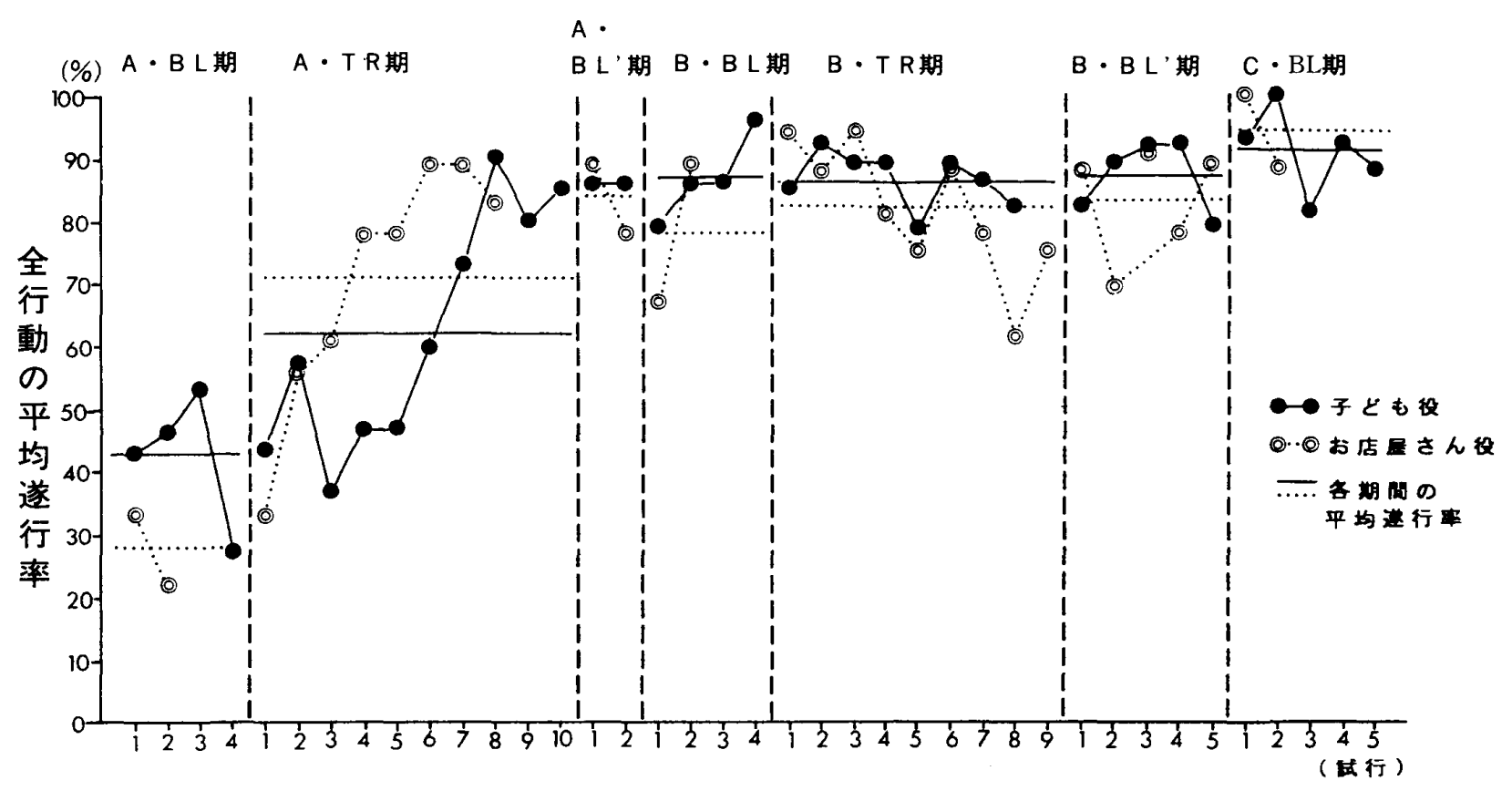

Fig. 1 台本を構成する全行動の平均遂行率の推移 


\section{ごっこ遊び場面における重度精神遅滞児のコミュニケーション行動の指導}

降、「ダダイ」を自発している。B・Tr期以降、プロン プトによる遂行の水準に戻った。

4 ）行動(7)「どうぞ」：A・BL 期で身ぶり、言葉 いずれも発せず、A・Tr期ではプロンプトにより身ぶ りや発話で遂行した。 $\mathrm{A} \cdot \mathrm{BL}$ 期、B・BL 期で「ド」あ るいは「ハイ」を自発した。 $\mathrm{B} ・ \mathrm{Tr}$ 期、B・BL'期およ びC・BL 期で「ドード」あるいはイントネーションが 似ている「ダータ」を自発した。

3. 台本に含まれないコミュニケーション行動の推 移 (Table 2)

$\mathrm{A} \cdot \mathrm{BL}$ 期〜 $\mathrm{B} \cdot \mathrm{BL}$ 期および $\mathrm{B} \cdot \mathrm{BL}$ 期の各期の平均 頻度は、全セッションの平均頻度より低い。B・Tr 期 以降の各期の平均頻度はそれ以前の平均頻度より高
い。最頻值を示したコミュニケーションの形態は、A・ $\mathrm{BL}$ 期〜 B・BL 期は主に遠ジェスチュアーで、 B・Tr 期以降は真のサイン・言語が多い、という傾向が認め られる。真のサイン・言語に分類された発話の大部分 は、お客をしばらく待たせるために発した「マッテ」、 エプロンの紐結びを Prに求める時発した「ヤッテ」で あった。

IV. 考 察
1. ごっこ遊びルーティンの形成と同じテーマの遊 びへの般化

台本 $\mathrm{A}$ の指導が始まると、各行動は速やかに形成さ れ、プロンプトを除去した $\mathrm{A} ・ \mathrm{BL}$ 期でも維持された。
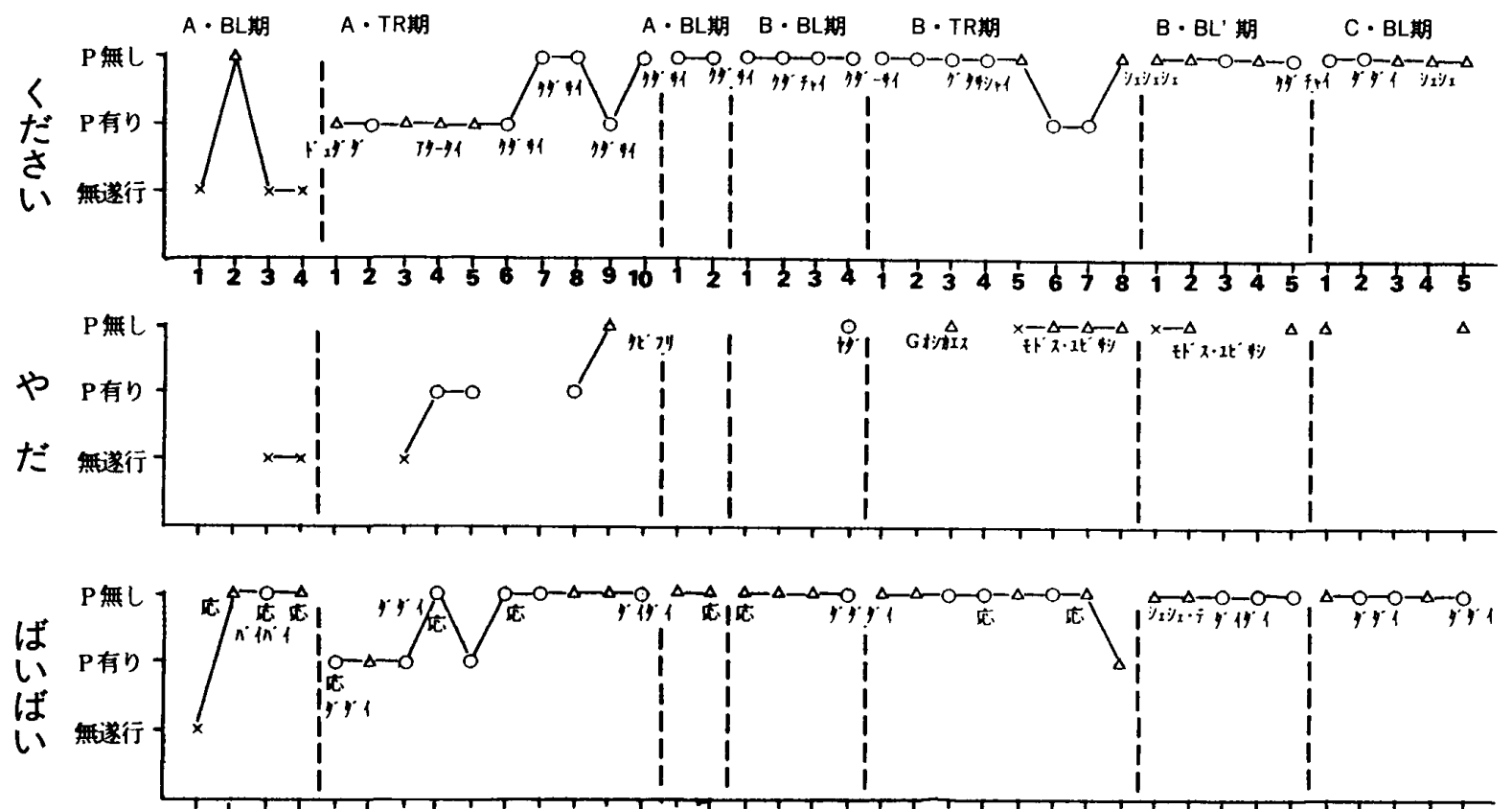

Fig. 2-1 標的コミュニケーション行動の指導経過（子ども役）

(鼓行)

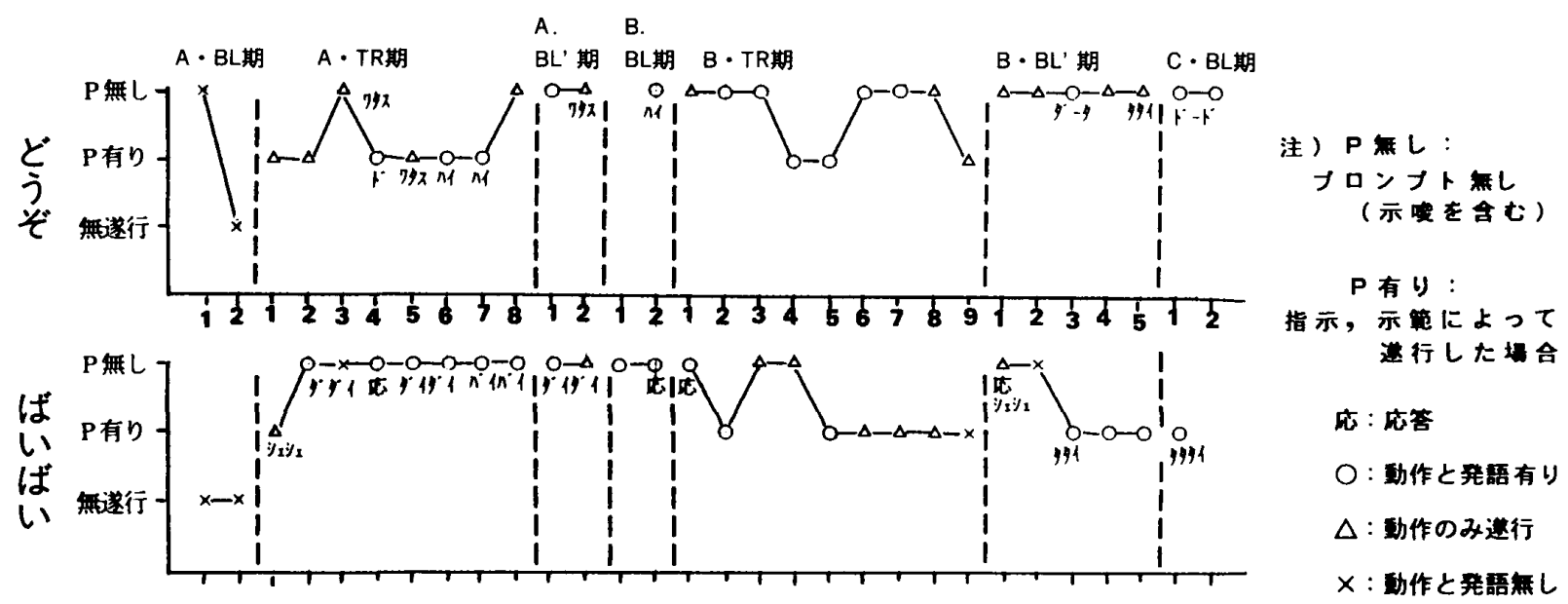

Fig. $2-2$ 標的コミュニケーション行動の指導経過（お店屋さん役） 
Table 2 お店場面における台本に含まれないコミュニケーション行動の頻度

\begin{tabular}{|c|c|c|c|c|c|c|c|c|c|c|c|c|c|c|c|c|c|c|}
\hline \multirow{2}{*}{$\begin{array}{c}\text { 指導期 } \\
\text { セツシ }\end{array}$} & \multicolumn{2}{|c|}{$A \cdot B L$} & \multicolumn{4}{|c|}{$A \cdot \operatorname{Tr}$} & \multirow{2}{*}{$\frac{\mathrm{A} \cdot \mathrm{BL}^{\prime}}{7}$} & \multicolumn{2}{|c|}{$\mathrm{B} \cdot \mathrm{BL}$} & \multicolumn{4}{|c|}{$\mathrm{B} \cdot \mathrm{Tr}$} & \multicolumn{2}{|c|}{$\mathrm{B} \cdot \mathrm{BL}^{\prime}$} & \multicolumn{2}{|c|}{$\mathrm{C} \cdot \mathrm{BL}$} & \multirow{2}{*}{ 計 } \\
\hline & 1 & 2 & 3 & 4 & 5 & 6 & & 8 & 9 & 10 & 11 & 12 & 13 & 14 & 15 & 16 & 17 & \\
\hline 接触ジェスチュアー & 0 & 1 & 1 & 0 & 1 & 0 & 0 & 2 & 1 & 1 & 1 & 3 & 2 & 2 & 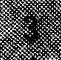 & 1 & 3 & 22 \\
\hline 遠ジェスチュアー & 2. & 1 & 2 & 0 & (2) & 2 & 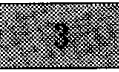 & 0 & 0 & (2) & 2 & 1 & (3) & 2 & 0 & 1 & 3 & 31 \\
\hline 真のサイン・言語 & 0 & 1 & 0 & 0 & 2 & 1 & 0 & 1 & 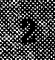 & & (3) & ) & 2 & 2 & 0 & 1 & $\sqrt{3}$ & 30 \\
\hline 計 & 2 & 3 & 3 & 0 & 7 & 3 & 3 & 3 & 3 & 11 & 7 & 9 & 7 & 6 & 3 & 3 & 10 & 83 \\
\hline 平均頻 度 & & 5 & & & & & & & 0 & & 8. & 5 & & & 5 & 6 & .5 & 4.9 \\
\hline
\end{tabular}

$\mathrm{B} ・ \mathrm{BL}$ 期と $\mathrm{C} ・ \mathrm{BL}$ 期で高い遂行率を維持できたこと から、台本 $\mathrm{A}$ で形成したルーティンは、お店の構成や 品物の展示といった視覚的な次元で変化を加えた別の 買い物ごっこに容易に般化した、と言える。このこと は、遊びをルーティン化する指導を通して、特定の刺 激あるいは場面だけを手がかりとしたパターン化した 行動系列を形成しただけでなく、等価な他の刺激ある いは場面でも機能する遊びを形成したことを示す。こ の般化を促した理由は、3つの台本の展開がほぼ一定 だったために、機能的に等価な刺激を台本間で同定し、 各刺激に対応した行動を遂行しやすかったからである と考えられる。これら、ルーティンに扔いて刺激と反 応の順番が一定していることからコミュニケーション を含む行動の形成が促進され、またルーティンを構成 する要素に変化を加えることで、より弾力的なルー ティンになるという見解 (Snyder-McLean, Solomonson, McLean, and Sack, 19846)）を支持する。見立て 遊びが可能か下限に近い子ども（Wing，Gould， Yeates, and Brierley, 1977 ) ) を対象とする場合、遊 びを台本によってルーティン化する指導方略は、有効 であると考えられる。

\section{2. 標的としたコミュニケーション行動の形成と同} じテーマの遊びへの般化

$\mathrm{A} \cdot \mathrm{Tr}$ 期の後半から、身ぶりあるいは標㔼的な発音 に近い発語が安定して遂行されるようになった。この ことは、コミュニケーション行動自体は、此較的速く 形成できたことを示す。しかし、言葉の産出面に限れ ば、一度は標準的な発音に近い発語が発せられ、台本 Bに般化したが、既存の発声に戻ったり、身ぶりだけ に戻ることもあった。これは、形成した発語がまだ完 全には習得されず、本児にとって発しやすい発声に置 換されたためと考えられる。

標的としたコミュニケーション行動を発しなかった
時、示範して、模做させた。 $M$ 児は、この遊びに積極 的に参加するものの、コミュニケーション行動の修正 に対しては、概して拒否的であった。これは、発声指 導に対する拒絶反応の現れと考えられる。そのことが 契機となり、遊びそのものに対する拒否が生じること が予想された。そこで発声行動については、本児なり の特徵を許容することにした。しかし、明瞭な発声の 時に、賞䞇し、期待している発話行動を明確化する等、 更に細かな指導上の配慮が必要であった。

\section{3. その他のコミュニケーション行動への波及効果}

台本 $\mathrm{B}$ 指導期以降、台本に含まれないコミュニケー ション行動の頻度が増加する傾向が見られる。この背 景として、次のことが考えられる。台本 $\mathrm{A}$ 指導期では、 $\operatorname{Pr} も \mathrm{M}$ 児自身も買い物ごっこルーティンを形成する ことに注意を向けた結果、標的行動以外のコミュニ ケーション行動を自発することが抑制されたと考えら れる。 $\mathrm{A} \cdot \mathrm{BL}$ 期、B・BL 期で高い遂行率を維持したこ とから、この遊びのルーティンはこの時までに獲得さ れ、他の場面に般化したと言える。そのため、台本 B 指導期では、そのルーティンを学習する段階から自発 的に繰り返す段階になり、台本にない行動（「マッテ」 と言って, 進行を一時止める等）を遂行する機会も生 まれた、と考えられる。

\section{$V$ ．まとめと今後の課題}

本研究で、台本をほぼ一定に保ち、場面の配置等視 覚的な次元で変化を加えた場合、ごっこ遊びおよびコ ミュニケーション行動には容易に般化が生じられるこ とが分かった。また、このごっこ遊びルーティンに慣 れるに従って、別の行動や発話が自発される傾向が見 られた。これらの傾向は、ごっこ遊びの指導から、よ り遊びらしい活動に移行したことの反映とも考えられ る。今後の課題は、般化場面として別のデーマの遊び 


\section{ごっこ遊び場面における重度精神遅滞児のコミュニケーション行動の指導}

を設けた場合、コミュニケーション行動および遊び自 体が般化するか検討することである。

\section{文 献}

1) McLean, J. and Snyder-McLean, L. K. (1987) Form and function of communicative behavior among persons with severe developmental disabilities. Australia and New Zealand Journal of Developmental Disabilities, 13, 83-98.

2) 宮崎 真 (1992) 共同行為ルーティンによる重度 精神遅滞児のごっこ遊び、コミュニケーション 行動の促進. 特殊教育学研究, 29(4), 105-110.

3) 宮崎 真 (1995) 重度遅滞を持つ児童に対する ごっこ遊び場面での言語指導. 行動療法研究, 21(1), 15-24.

4) Stokes, T. F. and Baer, D. M. (1977) An implicit technology of generalization. Journal of Applied
Behavior Analysis, 10, 349-367.

5) Strain, P. S. and Wiegerink, R. (1976) The effects of sociodramatic activities on social interaction among behaviorally disordered preschool children. Journal of Special Education, 10, 71-75.

6) Snyder-McLean, L. K., Solomonson, B., McLean, J. E., and Sack, S. (1984) Structuring joint action routines: A strategy for facilitating communication and language development in the classroom. Seminars in Speech and Language, 5, 213-228.

7) Wing, L., Gould, J., Yeates, S. R., and Brierley, L. M. (1977) Symbolic play in severely mentally retarded and in autistic children. Journal of Child Psychology and Psychiatry, 18, 167-178. - 1995.1.26. 受稿, 1996.2.17. 受理一 